\title{
Increasing the use of anti-inflammatory agents for acute asthma in the emergency department: Experience with an asthma care map
}

\author{
Brian H Rowe MD MSc ${ }^{1,2}$, Anthony M Chahal MD MASc ${ }^{3}$, Carol H Spooner BScN MSc ${ }^{1}$, Sandra Blitz MSc ${ }^{1}$, \\ Ambikaipakan Senthilselvan PhD², Deborah Wilson MN , Brian R Holroyd MD ${ }^{1}$, Michael Bullard MD ${ }^{1}$
}

\begin{abstract}
BH Rowe, AM Chahal, CH Spooner, et al. Increasing the use of anti-inflammatory agents for acute asthma in the emergency department: Experience with an asthma care map. Can Respir J 2008;15(1):20-26.
\end{abstract}

PURPOSE: Acute asthma is a common emergency department (ED) presentation and variation in its management is well recognized. The present study examined the use of an asthma care map (ACM) in one Canadian ED to improve adherence to acute asthma guidelines, emphasizing the use of systemic corticosteroids (SCSs) and inhaled corticosteroids (ICSs).

METHODS: Three time periods were studied: the 15 months before ACM introduction (PRE), the 15 months following a threemonth introduction of the ACM (POST 1 ) and the 18 months after $\mathrm{POST}_{1}\left(\mathrm{POST}_{2}\right)$. Randomly selected patient charts from each period were included from patients who were 18 to 60 years of age and presented with a primary diagnosis of acute asthma. A priori criteria were established to determine the degree of completion and success of the ACM. Primary outcomes included documentation, use of SCSs in the ED, and prescription of SCSs and ICSs at ED discharge.

RESULTS: A total of 387 patient charts were included (PRE, $\mathrm{n}=150 ; \mathrm{POST}_{1}, \mathrm{n}=150 ; \mathrm{POST}_{2}, \mathrm{n}=87$ ). Patient characteristics in the three groups were similar; however, patients in $\mathrm{POST}_{1}$ and $\mathrm{POST}_{2}$ showed higher use of newer agents than those in the PRE group. Overall, more women $(n=209 ; 54 \%)$ than men were seen; the mean age was 32.4 years. The care map was used in $67 \%$ of cases during $\mathrm{POST}_{1}$ and $70 \%$ during $\mathrm{POST}_{2}$. The use of peak expiratory flow (PEF) was high during the PRE, POST $_{1}$ and $\mathrm{POST}_{2}$ periods (91\%, 89\% and 91\%, respectively); however, documentation of other markers of severity increased in the POST periods. Use of SCSs occurred earlier $(\mathrm{P}<0.01)$ and more often $(57 \%$ PRE, $68 \%$ $\mathrm{POST}_{1}$ and $\left.75 \% \mathrm{POST}_{2} ; \mathrm{P}<0.01\right)$ in the $\mathrm{POST}_{1,2}$ periods than the PRE period. There was a significant increase in use of SCSs on discharge (55\% PRE, 66\% $\mathrm{POST}_{1}$ and $69 \% \mathrm{POST}_{2} ; \mathrm{P}<0.05$ ), and prescription of ICSs significantly increased (24\% PRE, 45\% POST $_{1}$ and $\left.61 \% \mathrm{POST}_{2} ; \mathrm{P}<0.001\right)$ in the $\mathrm{POST}_{1,2}$ periods. Discharge without any corticosteroids decreased over the three periods (32\% PRE, $21 \% \mathrm{POST}_{1}$ and $\left.17 \% \mathrm{POST}_{2} ; \mathrm{P}<0.05\right)$. The length of stay in the ED increased over the study periods (181 min PRE, $209 \mathrm{~min} \mathrm{POST}_{1}$ and 265 min $\left.\mathrm{POST}_{2} ; \mathrm{P}<0.01\right)$ and admissions were infrequent $(9 \%$ PRE, $13 \% \mathrm{POST}_{1}$ and $\left.6 \% \mathrm{POST}_{2} ; \mathrm{P}=0.50\right)$.
CONCLUSIONS: The present study provides evidence that the standardized ED ACM was widely accepted, improved chart documentation, improved some aspects of ED care and increased prescribing of discharge preventive medications.

Key Words: Asthma; Corticosteroids; Guidelines; Prevention

Utilisation accrue d'anti-inflammatoires dans le traitement de l'asthme aigu à l'urgence : l'expérience d'un cheminement clinique pour l'asthme

BUT : L'asthme aigu est un motif fréquent de consultation à l'urgence, et les différences de traitement sont bien connues. La présente étude avait pour but d'examiner l'utilisation d'un cheminement clinique (CC) ( « carte de soins ») pour l'asthme dans un service des urgences au Canada afin d'améliorer le respect des lignes directrices sur l'asthme aigu, qui préconisent l'utilisation de corticostéroïdes généraux (CG) et de corticostéroïdes en inhalation (CI).

MÉTHODE : Le temps à l'étude a été divisé en trois périodes : 15 mois avant l'application du CC (PRE), 15 mois suivant une période d'essai de trois mois du CC $\left(\mathrm{POST}_{1}\right)$ et 18 mois après la POST $\left.\mathrm{POST}_{2}\right)$. Nous avons choisi au hasard des dossiers de patients âgés de 18 à 60 ans, qui provenaient de chacune des périodes et chez qui un diagnostic principal d'asthme aigu avait été posé. Nous avons également établi au préalable des critères afin de déterminer le degré de réalisation et de réussite du CC. Les principaux critères d'évaluation comprenaient la documentation, l'utilisation du CC à l'urgence ainsi que la prescription de CG et de CI au moment du congé de l'urgence.

RÉSULTATS : Au total, 387 dossiers de patients ont été retenus (PRE : $\mathrm{n}=150 ; \mathrm{POST}_{1}: \mathrm{n}=150 ; \mathrm{POST}_{2}: \mathrm{n}=87$ ). Les malades, dans les trois groupes, avaient des caractéristiques comparables; cependant, l'utilisation de nouveaux médicaments était plus grande dans les groupes POST $_{1}$ et $\mathrm{POST}_{2}$ que dans le groupe PRE. Dans l'ensemble, plus de femmes ( $\mathrm{n}=209$; $54 \%$ ) que d'hommes ont consulté, et l'âge moyen était de 32,4 ans. Le CC a été utilisé dans $67 \%$ des cas dans le groupe POST 1 et dans $70 \%$ des cas dans le groupe $\mathrm{POST}_{2}$. La mesure du débit expiratoire de pointe s'est révélée un indicateur fréquent pendant les périodes $\mathrm{PRE}, \mathrm{POST}_{1}$ et POST $_{2}$ (91 \%, $89 \%, 91 \%$ respectivement), mais l'utilisation d'autres marqueurs de gravité a augmenté pendant les périodes POST. Nous avons également noté une utilisation plus précoce $(\mathrm{P}<0,01)$ et plus fréquente

suite a la page 21

${ }^{1}$ Department of Emergency Medicine; ${ }^{2}$ Department of Public Health Sciences, University of Alberta, Edmonton, Alberta; ${ }^{3}$ Department of Emergency Medicine, University of British Columbia, Vancouver, British Columbia; ${ }^{4}$ Alberta Medical Association Toward Optimized Practice Program, Edmonton, Alberta

Correspondence: Dr Brian H Rowe, Department of Emergency Medicine, University of Alberta, 1G1.43 Walter Mackenzie Health Sciences Centre, 8440 - 112 Street, Edmonton, Alberta T6G 2B7. Telephone 780-407-6761, fax 780-407-3982,

e-mail Brian.Rowe@ualberta.ca 
(PRE : $57 \%$; POST $_{1}$ : $68 \%$; POST $_{2}$ : $75 \%$; P<0,01) de CG au cours des périodes $\mathrm{POST}_{1}$ et $\mathrm{POST}_{2}$ qu'au cours de la période PRE. L'utilisation de CG a augmenté de façon significative au moment du congé (PRE : $55 \%$; $\mathrm{POST}_{1}$ : $66 \%$; $\mathrm{POST}_{2}$ : $69 \%$; $\left.\mathrm{P}<0,05\right)$, de même que la prescription de CI pendant les périodes $\mathrm{POST}_{1}$ et $\mathrm{POST}_{2}$ (PRE : $24 \%$; $\mathrm{POST}_{1}: 45 \%$; $\left.\mathrm{POST}_{2}: 61 \% ; \mathrm{P}<0,001\right)$. Par contre, une diminution du nombre de congés sans prescription de corticostéroïdes a été constatée au cours des trois périodes (PRE : $32 \%$; POST $_{1}: 21 \%$; POST $_{2}: 17 \% ; \mathrm{P}<0,05$ ). Enfin, la durée du séjour à l'urgence a augmenté pendant les périodes à l'étude
(PRE : $181 \mathrm{~min}$ POST $_{1}: 209 \mathrm{~min} ; \mathrm{POST}_{2}: 265 \mathrm{~min}$; P<0,01), mais le pourcentage d'hospitalisations, lui, est demeuré faible (PRE : $9 \%$; $\mathrm{POST}_{1}$ : $\left.13 \% ; \mathrm{POST}_{2}: 6 \% ; \mathrm{P}<0,50\right)$.

CONCLUSION : La présente étude a montré que l'application d'un modèle uniforme de cheminement clinique pour l'asthme à l'urgence avait été très bien acceptée et qu'elle avait permis d'améliorer la documentation au dossier ainsi que certains aspects des soins fournis à l'urgence, en plus d'accroître la prescription de médicaments prophylactiques au moment du congé.

The interventions were approved by the UAH emergency physician group, and a prototype was used for three months before final printing. The introduction of the ACM was accompanied by extensive continuing medical education sessions, and feedback was returned to ED staff. Respiratory therapists were provided with training and given approval to initiate care before physician assessment; however, physicians were informed and assessed patients soon after ACM initiation.

\section{Inclusion and exclusion criteria}

All patients between 18 and 60 years of age who presented to the ED with a primary diagnosis of acute asthma (International Classification of Diseases, Ninth Revision, Clinical Modification, code 493. $\times$ ) were eligible. Patient charts were excluded if treatment was not provided in the ED (eg, prescription renewals, very mild disease, etc), if diagnosis was miscoded (eg, community-acquired pneumonia, chronic obstructive pulmonary disease, etc), if the patient was transferred from other institutions and if the patient was directly transferred to a specialist.

\section{Data sources}

A random sample of patient charts that met inclusion criteria in each of the three time periods was selected using a computergenerated random numbers list (SPSS Inc, USA). The first time period (PRE) selected was the 15-month period (September 1997 to November 1998) before introducing the ACM. The second time period $\left(\mathrm{POST}_{1}\right)$ was the 15 -month period (March 1999 to May 2000) following a three-month introduction period of the ACM. The final time period $\left(\mathrm{POST}_{2}\right)$ studied was an 18-month period (September 2000 to March 2002) after the second evaluation.

\section{Data collection}

Data were abstracted from the patient charts by one of two trained research assistants using a standardized audit form. A priori criteria were established to determine the degree of complete documentation and the success of adhering to the ACM. Physicians were not aware of the study at the time of patient presentation in any of the time periods. Data were collected on demographics, asthma severity, medical history, presenting asthma description, ED treatment, outcome and discharge treatment.

\section{Outcomes}

The primary study outcomes were the proportion of patients administered systemic corticosteroids (SCSs) in the ED, and the number of prescribed SCSs and inhaled corticosteroids (ICSs) at discharge during each of the three time periods. Secondary outcomes included the use of the ACM and the changes in monitoring severity and overall documentation. 
TABLE 1

Demographic factors, use of asthma care map (ACM) and documentation of prevention in the preimplementation (PRE), postimplementation (POST 1 ) and maintenance $\left(\mathrm{POST}_{2}\right)$ phases of the asthma guideline implementation project

\begin{tabular}{|c|c|c|c|}
\hline Demographic factors & $\begin{array}{c}\text { PRE } \\
(n=150)\end{array}$ & $\begin{array}{l}\text { POST }_{1} \\
(n=150)\end{array}$ & $\begin{array}{l}\text { POST }_{2} \\
(n=87)\end{array}$ \\
\hline Age, years, mean $\pm S D$ & $31.3 \pm 10.3$ & $32.9 \pm 12.8$ & $33.1 \pm 14.2$ \\
\hline Female patients, $\%$ & 54 & 53 & 56 \\
\hline Primary care physician identified, \% & 75 & 78 & 77 \\
\hline ACM initiated ${ }^{*}, \%$ & 8 & 67 & 70 \\
\hline \multicolumn{4}{|l|}{ Complete documentation, $\%$} \\
\hline History & - & 58 & 55 \\
\hline Medication lists & - & 53 & 57 \\
\hline Treatments & - & 63 & 69 \\
\hline Discharge & - & 7 & $<1$ \\
\hline Nursing record on file ${ }^{\dagger}, \%$ & 79 & 48 & 70 \\
\hline \multicolumn{4}{|l|}{ Documentation of preventive measures, $\%$} \\
\hline Use of spacer device for beta-agonists* & 7 & 49 & 56 \\
\hline Asthma action plan during exacerbations* & 0 & 8 & 61 \\
\hline Measurement of PEF in the ED, \% & 91 & 89 & 91 \\
\hline
\end{tabular}

${ }^{*} P \leq 0.001 ;{ }^{\dagger} P \leq 0.05$. ED Emergency department; PEF Peak expiratory flow; $P R E$ Fifteen-month phase before ACM initiation; $P O S T_{1}$ Fifteen-month phase following three months of ACM initiation; POST 2 Eighteen-month phase after $\mathrm{POST}_{1}$

Validity of collected data

Data extracted from a random selection of 60 charts in the PRE and $\mathrm{POST}_{1}$ periods were assessed by a second coder to determine data validity; intraclass correlation coefficient (ICC) and kappa $(\kappa)$ were calculated. Levels of agreement were assessed as excellent (ICC or $\kappa, 0.8$ or greater), good (ICC or $\kappa, 0.6$ or greater and less than 0.8 ), moderate (ICC or $\kappa, 0.4$ or greater and less than 0.6 ), fair (ICC or $\kappa, 0.2$ or greater and less than 0.4 ) or poor (ICC or $\kappa$ less than 0.2 ) (17).

\section{Statistical analysis}

Data were analyzed using the SPSS-PC (version 14.0) statistical software program (SPSS Inc, USA). Categorical values are reported as counts and percentages, and continuous variables are reported as mean $\pm \mathrm{SD}$ or as median and interquartile range. Comparisons among periods were made using ANOVA or Kruskal-Wallis rank tests, as appropriate, for continuous variables or Cochran's test for trends in categorical variables.

An analysis was undertaken to identify factors associated with receiving SCSs in the ED and ICSs after discharge. Univariate logistic regression models were developed. Any predictor that was significant $(\mathrm{P}<0.05)$ was entered into a stepwise logistic regression model $\left(\mathrm{P}_{[\text {to enter }]}=0.05 ; \mathrm{P}_{\text {[to stay] }}=0.10\right)$.

\section{Ethics}

The present study was approved by the University of Alberta Health Research Ethics Board. No informed consent was obtained for this retrospective study as per the Ethics Committee approval. Patient names and identifying characteristics were not kept, records remained stored in a secure area and only aggregate data are reported.

Chart selection

\section{RESULTS}

Overall, ED volumes increased from 58,930 visits in 1997 to 1998 , to 69,166 visits in 2001 to 2002 . In total, 460 asthma
TABLE 2

Chronic asthma factors of patients presenting in the preimplementation (PRE), postimplementation (POST 1 ) and maintenance $\left(\mathrm{POST}_{2}\right)$ phases of the asthma guideline implementation project

\begin{tabular}{lccc}
\hline Chronic asthma factors & $\begin{array}{c}\text { PRE } \\
\text { (n=150) }\end{array}$ & $\begin{array}{c}\mathbf{P O S T}_{\mathbf{1}} \\
(\mathbf{n = 1 5 0 )}\end{array}$ & $\begin{array}{c}\mathbf{P O S T}_{\mathbf{2}} \\
\text { (n=87) }\end{array}$ \\
\hline Smoker, \% & 24 & 29 & 18 \\
Number of years with asthma, mean \pm SD & $17 \pm 11$ & $17 \pm 13$ & $16 \pm 12$ \\
Ever intubated for asthma, \% & 10 & 4 & 10 \\
Medications on ED presentation, \% & & & \\
Theophylline & 11 & 10 & 3 \\
Oral corticosteroids & 14 & 15 & 14 \\
Inhaled beta-agonist & 82 & 81 & 80 \\
Inhaled corticosteroid & 53 & 60 & 45 \\
Inhaled long-acting beta-agonist ${ }^{*}$ & 9 & 13 & 20 \\
Inhaled ipratropium bromide & 15 & 19 & 6 \\
Leukotriene modifier ${ }^{\dagger}$ & 3 & 15 & 13 \\
Other asthma medications & 10 & 7 & 0 \\
\hline
\end{tabular}

${ }^{*} P \leq 0.05 ;{ }^{\dagger} P \leq 0.01$. ED Emergency department; PRE Fifteen-month phase before asthma care map initiation; POST, Fifteen-month phase following three months of asthma care map initiation; $P O S T_{2}$ Eighteen-month phase after POST

charts were retrieved (PRE, $\mathrm{n}=185 ; \mathrm{POST}_{1}, \mathrm{n}=174 ; \mathrm{POST}_{2}$, $\mathrm{n}=101$ ). A similar number of charts were excluded from each of the three study periods for the following reasons: no treatment $(n=24)$, miscoded $(n=31)$ and other exclusions $(n=18)$. The final evaluation was based on 387 patient records (PRE, $\left.\mathrm{n}=150 ; \operatorname{POST}_{1}, \mathrm{n}=150 ; \operatorname{POST}_{2}, \mathrm{n}=87\right)$.

\section{Reliability}

For key continuous variables, the agreement between chart abstractors was excellent (ICC 0.86 to 1.0 ). For key dichotomous variables, the agreement between chart abstractors was very good to excellent ( $\kappa 0.79$ to 1.0$)$.

\section{Use of care map}

The use of the prototype care map was observed in a small percentage of charts (8\%) before the official launching. Following official implementation, $101 \mathrm{POST}_{1}(67 \%)$ and $61 \mathrm{POST}_{2}$ (70\%) period charts had evidence of ACM use (Table 1). While asthma history, medication lists, treatments and PEF measurements were well documented, documentation of discharge plans on the ACM was infrequent.

\section{Patient demographics}

The mean $( \pm$ SD) age of patients was similar across the study periods $(32.4 \pm 12.2$ years); more women $(\mathrm{n}=209 ; 54 \%)$ than men were seen (Table 1). Most patients had a 16- or 17-year history of asthma, and $18 \%$ to $29 \%$ were smokers (Table 2). The majority of patients (77\%) identified a primary care physician (PCP).

\section{Pre-ED treatment}

Overall, beta-agonist use was very common (81\%) and ICS use was moderate $(54 \%)$, while oral corticosteroids $(14 \%)$ and theophylline (9\%) use were low; these proportions did not vary among study periods (Table 2). The use of long-acting beta-agonists (9\% PRE, 13\% $\mathrm{POST}_{1}, 20 \% \mathrm{POST}_{2}$ ) and leukotriene modifiers (3\% PRE, 15\% $\mathrm{POST}_{1}, 13 \% \mathrm{POST}_{2}$ ) 
TABLE 3

Acute asthma presentation of patients during the preimplementation (PRE), postimplementation (POST 1 ) and maintenance (POST ${ }_{2}$ ) phases of the asthma guidelines implementation project

\begin{tabular}{lccc}
\hline Presentation & $\begin{array}{c}\text { PRE } \\
(\mathbf{n = 1 5 0 )}\end{array}$ & $\begin{array}{c}\mathbf{P O S T}_{\mathbf{1}} \\
(\mathbf{n = 1 5 0 )}\end{array}$ & $\begin{array}{c}\mathbf{P O S T}_{\mathbf{2}} \\
(\mathbf{n = 8 7})\end{array}$ \\
\hline $\begin{array}{l}\text { Arrival by ambulance, \% } \\
\text { Onset of symptoms, \% }\end{array}$ & 13 & 10 & 13 \\
$<24 \mathrm{~h}^{*}$ & 70 & 64 & 56 \\
$24-72 \mathrm{~h}$ & 19 & 25 & 12 \\
$>72 \mathrm{~h}$ & 11 & 11 & 32 \\
Initial respiratory rate*, breaths/min & $24.7 \pm 8.4$ & $22.2 \pm 6.1$ & $22.8 \pm 7.6$ \\
Initial oxygen saturation, \% & $95.0 \pm 4.2$ & $95.0 \pm 4.3$ & $95.1 \pm 3.5$ \\
Initial systolic blood pressure, mmHg & $124.1 \pm 15.6$ & $124.3 \pm 16.5$ & $129.6 \pm 20.3$ \\
Initial pulse rate, beats/min & $99.6 \pm 19.5$ & $99.9 \pm 18.9$ & $98.3 \pm 18.0$ \\
Initial PEF (earliest peak flow), L/min & $279 \pm 125$ & $249 \pm 105$ & $281 \pm 107$ \\
\hline Values are
\end{tabular}

Values are expressed as mean $\pm S D$ unless otherwise specified. ${ }^{*} P \leq 0.05$. PEF Peak expiratory flow; PRE Fifteen-month phase before asthma care map initiation; POST $T_{1}$ Fifteen-month phase following three months of asthma care map initiation; POST 2 Eighteen-month phase after POST

was higher in $\mathrm{POST}_{1}$ and $\mathrm{POST}_{2}$ periods than in the PRE period.

\section{Asthma severity}

Patients presented with moderate to severe asthma using traditional measures of severity such as median PEF $(250 \mathrm{~L} / \mathrm{min}$; interquartile range $190 \mathrm{~L} / \mathrm{min}$ to $340 \mathrm{~L} / \mathrm{min}$ ), mean vital signs (pulse rate $99 \pm 19$ beats/min, respiratory rate $23 \pm 8$ breaths/min, systolic blood pressure $125 \pm 17 \mathrm{mmHg}$ ) and mean $\mathrm{O}_{2}$ saturation $(95 \pm 4 \%$ ). Most patients were ambulatory; however, approximately $12 \%$ arrived by ambulance. Time from symptom onset to presentation and assessment increased, with more patients delaying longer than $72 \mathrm{~h}$ before ED presentation (Table 3).

\section{Treatment in the ED}

The timing of first treatments with beta-agonists and anticholinergics were similar among the study periods; however, the total number of anticholinergic treatments during the $\mathrm{ED}$ stay was higher in the $\mathrm{POST}_{1}$ and $\mathrm{POST}_{2}$ periods than the PRE period (Table 4). SCSs were administered with increasing frequency (57\% PRE, 68\% $\mathrm{POST}_{1}$ and $75 \% \mathrm{POST}_{2} ; \mathrm{P}<0.01$ ) and earlier (less than $60 \mathrm{~min} ; \mathrm{P}<0.01$ ) over the study periods. PEF change and admission proportions were not statistically different among the study periods.

\section{Disposition and discharge treatments}

The total time asthma patients spent in the ED increased (181 min PRE, 209 min $\mathrm{POST}_{1}$ and $265 \mathrm{~min} \mathrm{POST}_{2}$; $\mathrm{P}<0.001$ ) (Table 5). Admission proportions did not statistically differ among the study periods (9\% PRE, 13\% $\mathrm{POST}_{1}, 5 \%$ $\mathrm{POST}_{2}$ ). Prescribing of SCSs at discharge increased over the study periods (55\% PRE, 66\% $\mathrm{POST}_{1}$ and $69 \% \mathrm{POST}_{2}$; $\mathrm{P}<0.05)$. Use of ICSs increased (24\% PRE, $45 \% \mathrm{POST}_{1}$ and $\left.61 \% \mathrm{POST}_{2} ; \mathrm{P}<0.001\right)$ while the frequency of discharge without any ICS or SCS decreased (32\% PRE, 21\% POST $_{1}$ and $\left.14 \% \mathrm{POST}_{2} ; \mathrm{P}<0.05\right)$ over time.
TABLE 4

Acute asthma treatment in the emergency department (ED) during the preimplementation (PRE), postimplementation $\left(\mathrm{POST}_{1}\right)$ and maintenance $\left(\mathrm{POST}_{2}\right)$ phases of the asthma guidelines implementation project

\begin{tabular}{|c|c|c|c|}
\hline Treatment measures in the ED & $\begin{array}{c}\text { PRE } \\
(n=150)\end{array}$ & $\begin{array}{l}\mathrm{POST}_{1} \\
(\mathrm{n}=150)\end{array}$ & $\begin{array}{l}\mathrm{POST}_{2} \\
(\mathrm{n}=87)\end{array}$ \\
\hline $\begin{array}{l}\text { Time from presentation to first inhaled } \\
\text { treatment, min, median (IQR) }\end{array}$ & $41(26-65)$ & $40(16-70)$ & $42(13-95)$ \\
\hline $\begin{array}{l}\text { Number of inhaled beta-agonists in } \\
\text { the first hour, median (IQR) }\end{array}$ & $1(0-2)$ & $1(0-2)$ & $1(1-2)$ \\
\hline $\begin{array}{l}\text { Number of inhaled beta-agonists } \\
\text { over the ED stay, median (IQR) }\end{array}$ & $3(1-4)$ & $3(2-4)$ & $3(2-4)$ \\
\hline $\begin{array}{l}\text { Number of inhaled anticholinergics } \\
\text { in the first hour, median (IQR) }\end{array}$ & $1(0-1)$ & $2(1-2)$ & $1(1-2)$ \\
\hline $\begin{array}{l}\text { Number of inhaled anticholinergics } \\
\text { the ED stay }{ }^{*} \text {, median (IQR) }\end{array}$ & $2(1-3)$ & $3(1-3)$ & $3(1-3)$ \\
\hline $\begin{array}{l}\text { Given corticosteroid treatment in } \\
\text { the ED*, \% }\end{array}$ & 57 & 68 & 75 \\
\hline $\begin{array}{l}\text { ED corticosteroid treatment less than } \\
60 \mathrm{~min}^{*}, \%\end{array}$ & 36 & 50 & 55 \\
\hline Given IV $\mathrm{MgSO}_{4}$ treatment in the ED, $\%$ & 3 & 6 & 6 \\
\hline Given ICS treatment in ED, \% & 6 & 9 & 5 \\
\hline Administered $\mathrm{O}_{2}$ in the $\mathrm{ED}^{*}, \%$ & 24 & 21 & 7 \\
\hline Final PEF (absolute), L/min, mean \pm SD & $403 \pm 133$ & $369 \pm 122$ & $378 \pm 109$ \\
\hline $\begin{array}{l}\text { Change in PEF (absolute), L/min, } \\
\text { mean } \pm \mathrm{SD}\end{array}$ & $128 \pm 97$ & $118 \pm 95$ & $108 \pm 106$ \\
\hline Admitted, \% & 9 & 13 & 5 \\
\hline
\end{tabular}

${ }^{*} P \leq 0.01$. ICS Inhaled corticosteroids; IQR Interquartile range; IV Intravenous; $\mathrm{MgSO}_{4}$ Magnesium sulphate; PEF Peak expiratory flow; PRE Fifteen-month phase before asthma care map initiation; POST 1 Fifteen-month phase following three months of asthma care map initiation; $P O S T_{2}$ Eighteen-month phase after POST

TABLE 5

Acute asthma treatment after discharge from the emergency department (ED) during the preimplementation (PRE), postimplementation (POST 1 ) and maintenance $\left(\mathrm{POST}_{2}\right)$ phases of the asthma guidelines implementation project

\begin{tabular}{|c|c|c|c|}
\hline & $\begin{array}{c}\text { PRE } \\
(n=112)\end{array}$ & $\begin{array}{l}\mathrm{POST}_{1} \\
(\mathrm{n}=116)\end{array}$ & $\begin{array}{l}\text { POST }_{2} \\
(n=71)\end{array}$ \\
\hline Sent home on systemic corticosteroids ${ }^{*}, \%$ & 55 & 66 & 69 \\
\hline Sent home on any $\mathrm{ICS}^{\dagger}, \%$ & 24 & 45 & 61 \\
\hline Sent home on prednisone plus ICS ${ }^{\dagger}, \%$ & 11 & 31 & 46 \\
\hline Sent home on neither prednisone nor ICS,$\%$ & 32 & 21 & 17 \\
\hline Sent home on beta-agonists ${ }^{\ddagger}, \%$ & 51 & 59 & 73 \\
\hline Sent home on antibiotics, $\%$ & 9 & 8 & 0 \\
\hline PCP follow-up documentation, \% & 56 & 59 & 62 \\
\hline Total ED time in minutes ${ }^{\dagger}$, median (IQR) & 181 & 209 & 265 \\
\hline
\end{tabular}

${ }^{*} P \leq 0.05 ;{ }^{\dagger} P \leq 0.001 ; \neq P \leq 0.01$. ICS Inhaled corticosteroids; IQR Interquartile range; $P C P$ Primary care physician; PRE Fifteen-month phase before asthma care map initiation; POST 1 Fifteen-month phase following three months of asthma care map initiation; $P O S T_{2}$ Eighteen-month phase after POST 1

Multivariate analysis

There was an increase in SCS use in the ED over the study periods. This time period effect was maintained in the multivariate model (adjusted OR 1.6, 95\% CI 1.0 to 2.7); first PEF and previous ICS use were also significant contributors to the 
final model. Similarly, the proportion of patients discharged on ICS increased during the study and only this time period effect was maintained in the multivariate model (adjusted OR 3.4, 95\% CI 1.5 to 7.6 ).

\section{DISCUSSION}

Asthma presentations to North American EDs are common, and previous research has demonstrated that many patients receive poor care, often with unsatisfactory outcomes (18). Despite the development and dissemination of numerous guidelines on recommended treatment for acute asthma, care gaps remain. An important care gap has been the suboptimal use of anti-inflammatory agents in the emergency setting $(18-20)$. The present three-period chart audit examined the effects of introducing an ACM in a large, urban ED to improve acute asthma care; it represents one of the most comprehensive ED-based studies ever published. Overall, acceptance of the ACM was high and, unlike other CPGs, its use and adherence has been sustained since its introduction. In fact, the ACM has now largely replaced nursing notes and is used almost exclusively to document the progress of asthma patients through their ED treatment. Despite this acceptance, however, there is one component of the ACM that physicians consistently do not use - the discharge planning section. Guidelines stress the importance of discharge planning for asthma patients, and despite an effort to enhance this, the ACM made minimal inroads here. Clearly, the role of education remains under-appreciated in this setting $(21,22)$. This multidisciplinary care plan has received suggestions for feedback, and updates have been accomplished; the iterative nature of the ACM must be recognized.

In addition, the ACM has had an important and impressive effect on the treatment of patients in the ED because more patients are receiving optimal treatment with antiinflammatory agents. Systematic reviews have demonstrated that SCSs should be administered early and often in the ED to reduce admission to the hospital (23). The ACM significantly increased SCS use in the ED from 57\% (PRE) to $75 \%$ $\left(\mathrm{POST}_{2}\right)$. Furthermore, SCSs were administered earlier (ie, during the first $60 \mathrm{~min}$ ) in a significantly higher proportion of patients after the introduction of the ACM (36\% PRE versus $55 \% \mathrm{POST}_{2}$ ). High-quality evidence also supports the use of SCSs following discharge (24) and suggests that most patients should have a trial of ICSs as well $(25,26)$. The number of patients sent home on SCSs remained relatively stable (55\% PRE versus 69\% POST $_{2}$ ); however, the number sent home on ICSs increased from 24\% PRE to 61\% $\mathrm{POST}_{2}$. Finally, there were other beneficial changes in care that were observed, such as a reduced use of antibiotics and oxygen in the ED. Use of repeated doses of anticholinergic agents has been advocated (27), and the ACM also increased the use of this class of drugs in the ED.

Despite many years of evidence that substantiates the importance of anti-inflammatory agents in asthma, the lag in uptake of this evidence can still be demonstrated $(28,29)$. Reasons for the lack of uptake of evidence in general, and CPGs specifically, are now well documented $(11,30)$. Evidencebased guidelines have met with considerable obstacles, and litthe research can be found on ways to overcome them. A MEDLINE search for articles describing the impact of the care map or guideline use in adults was unproductive. While some publications documented guideline use in pediatric asthma
(31), their impact has only been modestly successful. One before and after study in a single United States adult ED indicated that a CPG improved processes of care and improved care in acute asthma (32). This study was conducted almost a decade ago, and our study differs in the focus of the intervention (anti-inflammatories), the study delivery and the influence of ED overcrowding on the results. Despite these differences, both studies suggest an ACM will improve process and care in the ED setting.

The success of the current ACM may be due to the multifaceted approach taken in its development and dissemination, which conforms with current knowledge about effective methods of changing practice (29). First, development took an evidence-based approach through a close-working, multidisciplinary team, including generalist and specialist clinicians. The group exercised ready acceptance of quality suggestions and sought feedback from all staff - suggestions that were reflected in the updates of the ACM form before final printing. The tool is easily available throughout the ED and assists decisions and care at the bedside. Its introduction was accompanied by frequent education sessions until all ED staff were aware of its existence. Though there is work still to be done, the ongoing popularity of the ACM leaves room for further improvements. For example, work is underway on a fully electronic interactive ACM that will be tested in this environment.

\section{Limitations}

Every attempt was made in the present study to eliminate bias; however, there are several possible limitations that should be considered. First, this study was a time series and, therefore, we cannot rule out the possibility that clinical advances may have influenced the results over time. We are relatively confident, however, that this did not occur because other 'newer' evidence has not influenced this field. No new guidelines for ED management of asthma were developed in Canada during the study period, and an updated version of the CTS/CAEP Guidelines has not resulted in a change in recommended anti-inflammatory agents in the ED or at discharge (33). In addition, mulitvariable models consistently identified time period as a significant factor associated with the increase use of SCS and ICS. Second, it is also possible that data collection was biased toward favourable results; however, this is unlikely, because there was excellent agreement between the two independent data collectors. Third, as with all chart reviews, legibility and inadequate documentation were problems. Although this made some categories of data extraction more difficult, it did not significantly affect the primary outcome results because treatment choices are well documented in all hospital-based patient charts. Fourth, we did not follow up patients to determine the influence of these changes on clinical outcomes; this would have dramatically increased the cost and complexity of the study (13). Moreover, the design (retrospective) precluded valid clinical outcome ascertainment. Our goal, however, was to enhance the use of anti-inflammatories in the ED and following discharge, not to re-prove the effectiveness of this mode of treatment. Fifth, while the use of evidence-based treatments increased, so did the ED length of stay. There are many potential explanations for this, including the crisis of ED overcrowding; further research on this is needed. Finally, the study was also limited to a single centre (UAH) and the 
generalizability of these results in other centres awaits confirmation. For example, large randomized controlled trials of $\mathrm{ACM}$, as have been performed in primary care, are needed to enhance the validity and applicability of ACMs (34).

\section{CONCLUSIONS}

Notwithstanding the above concerns, the findings from the present study suggest that the development of an evidencebased, multidisciplinary ACM for acute asthma was associated with widespread acceptance, without the traditional decay period seen in other forms of CPGs. In this setting, the ACM has produced impressive improvements in administering recommended anti-inflammatory treatment.

There is a substantial opportunity to improve management and reduce morbidity caused by asthma among these high-risk patients, and care maps represent one method of knowledge

\section{REFERENCES}

1. Camargo CA Jr, Richardson LD. Epidemiology of asthma. In: Brenner BE, ed. Emergency Asthma. New York: Marcel Dekker, 1998.

2. Mannino DM, Homa DM, Pertowski CA, et al. Surveillance for asthma - United States, 1960-1995. MMWR 1998;47:1-28.

3. Salmeron S, Liard R, Elkharrat D, Muir J, Neukirch F, Ellrodt A. Asthma severity and adequacy of management in accident and emergency departments in France: A prospective study. Lancet 2001;358:629-35.

4. Weiss KB, Sullivan SD, Lyttle CS. Trends in the cost of illness for asthma in the United States, 1985-1994. J Allergy Clin Immunol 2000;106:493-9.

5. Weiss KB, Sullivan SD. The health economics of asthma and rhinitis. I. Assessing the economic impact. J Allergy Clin Immun 2001;107:3-8.

6. Krahn MD, Berka C, Langlois P, Detsky AS. Direct and indirect costs of asthma in Canada. Can Med Assoc J 1996;154:821-31.

7. Beveridge RC, Grunfeld AF, Hodder RV, Verbeek PR. Guidelines for the emergency management of asthma in adults. CAEP/CTS Asthma Advisory Committee. Canadian Association of Emergency Physicians and the Canadian Thoracic Society. CMAJ 1996;155:25-37.

8. Boulet LP, Becker A, Bérubé D, Beveridge R, Ernst P. Canadian Asthma Consensus Report, 1999. CMAJ 1999;161(11 Suppl):S1-S61.

9. National Asthma Education and Prevention Program. Expert Panel Report II: Guidelines for the Diagnosis and Management of Asthma. Bethesda: National Institutes of Health; 1997.

10. British Thoracic Society, Scottish Intercollegiate Guidelines Network. British guideline on the management of asthma. Thorax 2003;58(Suppl 1):i1-94.

11. Cabana MD, Rand CS, Powe NR, et al. Why don't physicians follow clinical practice guidelines? A framework for improvement. JAMA 1999;282:1458-65.

12. Reid J, Marciniuk DD, Cockcroft DW. Asthma management in the emergency department. Can Respir J 2000;7:255-60.

13. Fitzgerald JM, Hargreave FE. Acute asthma: Emergency department management and prospective evaluation of outcome. CMAJ 1990;15:591-5.

14. Krym VF, Crawford B, Macdonald RD. Compliance with guidelines for emergency management of asthma in adults: Experience at a tertiary care teaching hospital. CJEM 2004;6:321-6.

15. Marrie TJ, Lau CY, Wheeler SL, Wong CJ, Vandervoort MK, Feagan BG. A controlled trial of a critical pathway for treatment of community-acquired pneumonia. CAPITAL Study Investigators. Community-Acquired Pneumonia Intervention Trial Assessing Levofloxacin. JAMA 2000;283:749-55.

16. Jadad AR, Moher M, Browman GP, et al. Systematic reviews and meta-analyses on treatment of asthma: Critical translation at the point of care. An evaluation of the effect of these interventions is important in the ongoing effort to provide optimal, timely care in busy ED settings. Future studies should focus on measures of improving process of care and evaluation of long-term clinically relevant outcomes.

ACKNOWLEDGEMENTS: The authors thank the Alberta Medical Association (AMA) Toward Optimized Practice (TOP) Clinical Practice Guidelines Program and the Department of Emergency Medicine Research Group (EMeRG) Program for supporting this research. The authors thank Leslie Tyler, Christina Douglas and University of Alberta Hospital Medical Records for their assistance. Dr Brian H Rowe is funded by the Government of Canada as a 21st Century Canada Research Chair. Dr Anthony M Chahal was supported by an Alberta Heritage Foundation for Medical Research (AHFMR) Summer Studentship award.

evaluation. BMJ 2000;320:537-40. (Errata in 2000;320:984 and 2000;321:275).

17. Kramer MS, Feinstein AR. Clinical biostatistics. LIV. The biostatistics of concordance. Clin Pharmacol Ther 1981;29:111-23. (Erratum in 1989;29:111-23).

18. Emerman CL, Woodruff PG, Cydulka RK, Gibbs MA, Pollack CV Jr, Camargo CA. Prospective multicenter study of relapse following treatment for acute asthma among adults presenting to the emergency department. MARC investigators. Multicenter Asthma Research Collaboration. Chest 1999;115:919-27.

19. Grunfeld A, Beveridge RC, Berkowitz J, FitzGerald JM. Management of acute asthma in Canada: An assessment of emergency physician behaviour. J Emerg Med 1997;15:547-56.

20. Emond SD, Camargo CA Jr, Nowak RM. 1997 National Asthma Education and Prevention Program guidelines: A practical summary for emergency physicians. Ann Emerg Med 1998;31:579-89.

21. Côté J, Bowie DM, Robichaud P, Parent JG, Battisti L, Boulet LP. Evaluation of two different educational interventions for adult patients consulting with an acute asthma exacerbation. Am J Respir Crit Care Med 2001;163:1415-9.

22. Emond SD, Reed CR, Graff LG IV, Clark S, Camargo CA Jr, on behalf of the MARC Investigators. Asthma education in the emergency department. Ann Emerg Med 2000;36:204-11.

23. Rowe BH, Spooner C, Ducharme FM, Bretzlaff JA, Bota GW. Early emergency department treatment of acute asthma with systemic corticosteroids. Cochrane Database Syst Rev 2001:CD002178.

24. Rowe BH, Spooner CH, Ducharme FM, Bretzlaff JA, Bota GW. Corticosteroids for preventing relapse following acute exacerbations of asthma. Cochrane Database Syst Rev 2001:CD000195.

25. Rowe BH, Bota GW, Fabris L, Therrien SA, Milner RA, Jacono J. Inhaled budesonide in addition to oral corticosteroids to prevent asthma relapse following discharge from the emergency department: A randomized controlled trial. JAMA 1999;281:2119-26.

26. Edmonds ML, Camargo CA, Saunders LD, Brenner BE, Rowe BH. Inhaled steroids in acute asthma following emergency department discharge. Cochrane Database Syst Rev 2000:CD002316.

27. Stoodley RG, Aaron SD, Dales RE. The role of ipratropium bromide in the emergency management of acute asthma exacerbation: A meta-analysis of randomized clinical trials. Ann Emerg Med 1999;34:8-18.

28. Lau J, Antman EM, Jimenez-Silva J, Kupelnick B, Mosteller F, Chalmers TC. Cumulative meta-analysis of therapeutic trials for myocardial infarction. New Engl J Med 1992;327:248-54

29. Davis DA, Taylor-Vaisey A. Translating guidelines into practice. A systematic review of theoretic concepts, practical 


\section{Rowe et al}

experience and research evidence in the adoption of clinical practice guidelines. CMAJ 1997;157:408-16.

30. Hayward RS, Guyatt GH, Moore KA, McKibbon KA, Carter AO. Canadian physicians' attitudes about and preferences regarding clinical practice guidelines. CMAJ 1997;156:1715-23.

31. Scribano PV, Lerer T, Kennedy D, Cloutier MM. Provider adherence to a clinical practice guideline for acute asthma in a pediatric emergency department. Acad Emerg Med 2001;8:1147-52.
32. Emond SD, Woodruff PG, Lee EY, Singh AK, Camargo CA Jr Effect of an emergency department asthma program on acute asthma care. Ann Emerg Med 1999;34:321-5.

33. Boulet LP, Bai TR, Becker A, et al. What is new since the last (1999) Canadian Asthma Consensus Guidelines? Can Respir J 2001;8(Suppl A):5A-27A.

34. Mitchell EA, Didsbury PB, Kruithof N, et al. A randomized controlled trial of an asthma clinical pathway for children in general practice. Acta Paediatr 2005;94:226-33. 


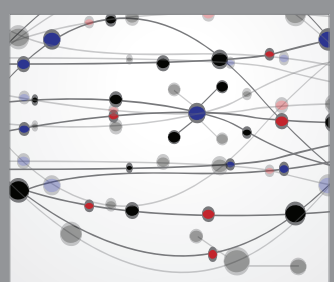

The Scientific World Journal
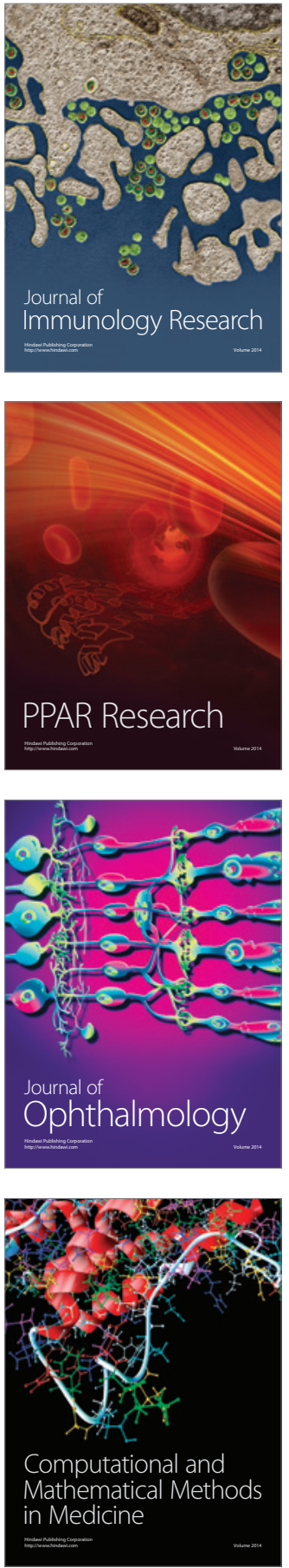

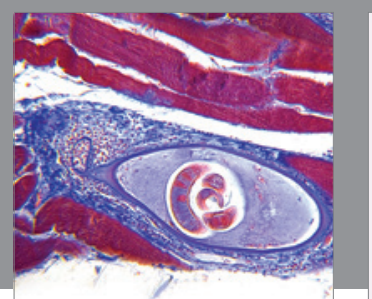

Gastroenterology Research and Practice

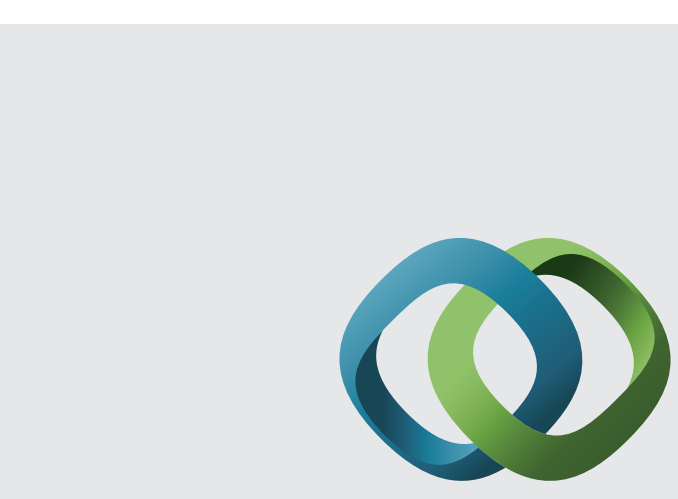

\section{Hindawi}

Submit your manuscripts at

http://www.hindawi.com
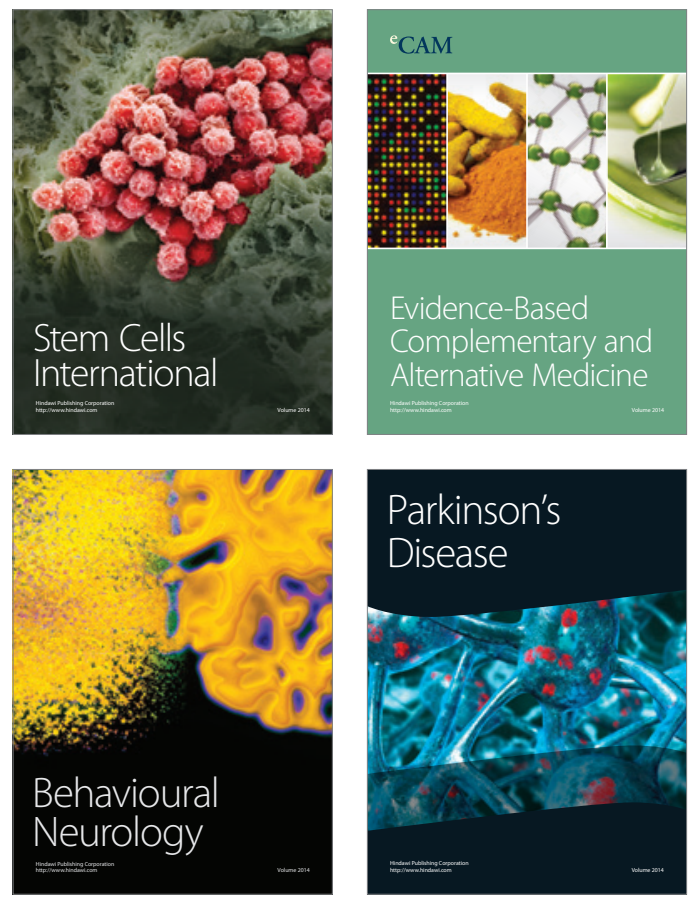
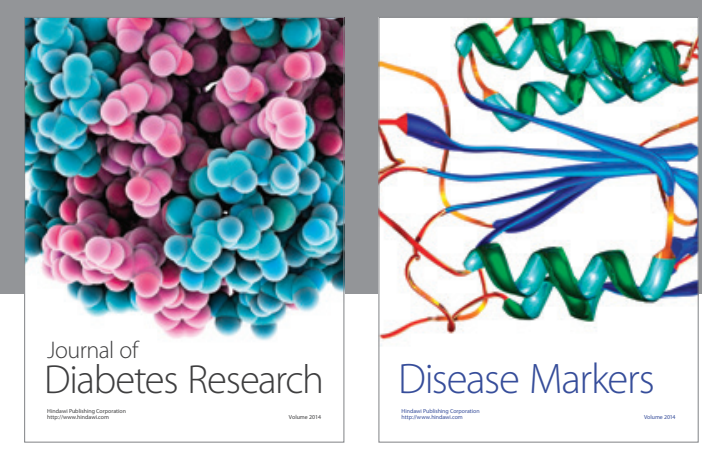

Disease Markers
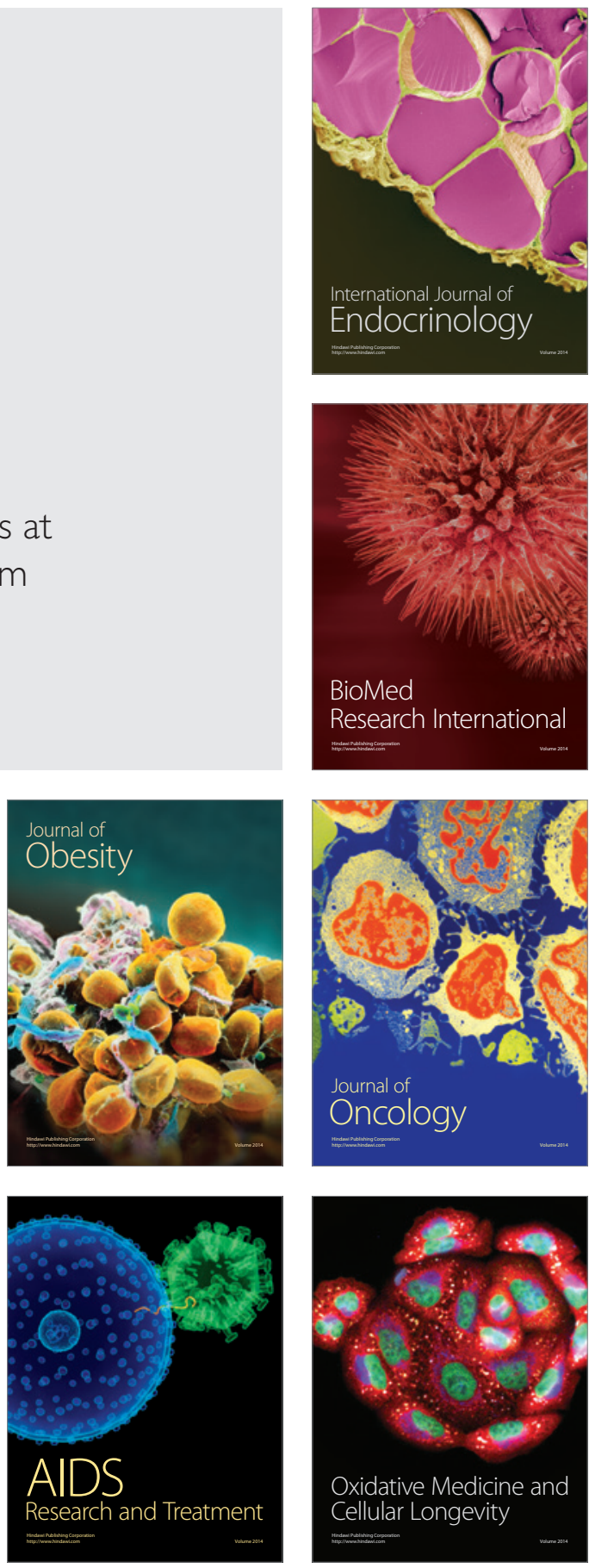